\title{
REPRESENTASI PATHET PADA GENDER WANDU MELALUI SISTEM DERET KEMPYUNG DALAM PENCIPTAAN KARYA MUSIK
}

\author{
Teteh Dayatami \\ Program Pascasarjana ISI Yogyakarta \\ Email: teteh.dayatami@gmail.com
}

\begin{abstract}
Abstrak
Penelitian ini fokus dalam menentukan metode penerapan pathet pada Gender wandu, menggunakan sistem deret kempyung dalam karya musik melalui sintesis unsur pathet laras pelog, pathet laras slendro, dan pathet laras wandu direpresentasikan menjadi konsep komposisi musikal. Metode penelitian menggunakan practice-led research didasarkan pada refleksi berulang serta relevansi praktik sehingga bagian-bagian praktikal dan relasi refeksi penelitian ini terdiri dari empat poin utama: review material, sintesis unsur pathet, eksperimen, dan evaluasi. Hasil penelitian adalah seleh pathet merupakan penerapan kombinasi kempyung dan penyilangan nada yang didasarkan oleh sistem deret kempyung dengan luaran led research berupa karya musik yang berjudul 'Pathet Gender Wandu'.
\end{abstract}

Kata kunci: Representasi, Pathet, Gender Wandu Sistem Deret Kempyung, Penciptaan Musik.

\begin{abstract}
The purpose of this research is to determine the method of applying pathet to the wandu Gender, using the kempyung series system in musical works through the synthesis of elements of the pelog barrel pathet, slendro barrel pathet, and wandu barrel pathet represented as the concept of musical composition. The research method using practice-led research is based on repeated reflection and relevance of practice so that the practical parts and relationships of research reflexion consist of four main points: material review, pathet element synthesis, experimentation, and evaluation.Result of this research is the pathet melt which is the application of a combination of kempyung and tone crossing based on the kempyung series system. Led research is in the form of a musical work titled 'Pathet Gender Wandu'.
\end{abstract}

Keywords: Representation, Pathet, Gender Wandu Kempyung Series, Music Creation. 


\section{A. Latar Belakang Masalah}

Pathet dan laras memiliki ikatan yang tidak bisa dipisahkan, dimana dalam karawitan Jawa suatu karya gending menggunakan sebuah laras saja, misalnya gending yang berjudul Ldr. Wilujeng menggunakan laras pelog pathet barang, Ldr. Mugi Rahayu menggunakan laras slendro pathet manyura. Selain dua laras tersebut, karawitan juga mengenal laras lain yaitu barang miring, atau bisa disebut minir, minur, atau minor (Supanggah, 2007:115). Pelaku seni meyakini bahwa garap laras barang miring merupakan penuangan laras pelog yang diaplikasikan ke dalam penyajian gending laras slendro. Oleh karena itu, dalam sebuah sajian gending laras slendro yang menggunakan nada pinjaman dari laras pelog barang miring telah tersirat sebuah rasa musikal gending dominan laras pelog, contohnya gending Tlutur Laras Slendro Barang Miring (Supanggah, 2007: 279).

Komposisi gending Jawa, terdapat pengolahan kedua laras yang dapat dikatakan unik. Pencampuran kedua laras tersebut berada pada gending yang berjudul Kodok Ngorek Laras Pelog. Gending ini memiliki gabungan dua laras, sajian gending Kodok Ngorek Laras Pelog secara keseluruhan menggunakan gamelan berlaras pelog, sedangkan pada instrumen Gender saja menggunakan laras slendro.
Kondisi tersebut bagi seniman karawitan tidak dianggap sebagai golongan laras yang lain (laras pelog dan slendro).

Pengalaman mengaransemen salah satu karya Ki Narto Sabdo yang berjudul Ktw. Ibu Pertiwi Laras Pelog Pathet Nem. Penulis mencampur semua pathet pada laras pelog dan laras slendro dalam bentuk vokal gerong atau koor dalam satu sajian yang diiringi gamelan gadon. Tumpang tindih bunyi yang dihasilkan dari kedua laras dan pathet tersebut menimbulkan efek yang tidak biasa namun berbeda dengan efek yang dihasilkan pada gending yang aslinya. Efek yang berbeda ini disebabkan karena perbedaan bunyi pernada, secara spesifiknya terletak pada perbedaan jumlah pathet yang sudah jelas berbeda semua karakternya. Eksplorasi dengan konsep campur pathet dan laras untuk selanjutnya terus penulis lakukan. ini terletak pada rasa seleh laras yang ditimbulkan oleh embat pada gamelan yang berbeda karena memiliki dua kebiasaan yang berbeda (Bali dan Jawa).

Hingga pada titik maksimal emosional penulis mengetahui sifat dan karakter yang semakin menjadi, penulis semakin tidak mau menerima keadaan wandu tersebut. Penulis membuat karya yang sangat berbeda dari karya-karya yang lain. Penulis membuat instrumen gender dengan cara meleburkan kedua laras pelog 
dan slendro menjadi satu instrumen.

Penulis mencampur Laras Pelog dan

Slendro dalam satu instrumen baru, dengan inovasi bentuk yang baru dan menamainya instrumen gender wandu. Penentuan nada dalam instrumen gender wandu tersebut menggunakan logika diantaranya. Jika nada $j i$ ke nada ro, maka nada diantara nada $j i$ dan nada ro menjadi nada ji pada instrumen gender wandu, dan seterusnya. Berlaku untuk laras pelog maupun laras slendro. Pelarasan yang dilakukan oleh penulis dan pengrajin gamelan pada saat pembuatan yakni menggunakan rumus kupingan (mengandalkan telinga) dan rasa yang wangun/pantas. Dapat dibayangkan rasa seleh pada laras wandu tersebut lebih mendominasi rasa yang ngambang/melayang dan terkesan tidak pada umumnya laras. Susunan nada pada instrumen gender wandu yaitu :

$\begin{array}{lllllllllll}5 \mathrm{~s} & 5 \mathrm{p} & 6 \mathrm{~s} & 7 & 1 \mathrm{p} & 1 \mathrm{~s} & 2 \mathrm{p} & 2 \mathrm{~s} & 3 & 5 \mathrm{~s} & 5 \mathrm{p}\end{array}$

$6 \mathrm{~s} \quad \dot{7}$ ip is $2 \mathrm{p}$ 2s $\dot{3}$

Keterangan: bunyi laras ini mirip dengan deretan nada-nada $G \quad A^{b}$ A $B$ C C\# D E $E^{b}$ E G A A B C C\# D $\mathrm{E}^{\mathrm{b}} \mathrm{E}$
Komposisi yang menggunakan instrumen gender wandu tersebut bisa digolongkan karya eksplorasi bunyi dari nada gamelan yang sudah ada dengan nada-nada dari instrumen gender wandu. Penulis tidak berfikir sejauh kearah pola tabuhan, pathet, bahlan bentuk gendingnya. Melainkan dengan cara dipukul nada-nada yang mirip dengan notasi Jawa pada umumnya. Tidak membuat gending, dan juga tidak memetakan apapun itu unsur laras pada gamelan.

Dari perjalanan eksplorasi yang sudah dilakukan sejauh ini, penulis menemukan adanya aspek yang perlu dilengkapi. Dikatakan kurang lengkap sebab jika gamelan tersebut harus memiliki pola tabuhan dan karakter atau pathet. Sedangkan pada gender laras $w a n d u$ ini belum memiliki pola tabuhan gender-an dan pathet/karakter.Sesungguhnya Pathet itu menjadi mutlak jika bertolak dari tradisi selama ini. Pathet menjadi suatu yang sangat penting dan yang menjadi pakem dalam karawitan Jawa. Bahwa pathet tersebut memiliki aturan yang mengikat dan menjadi sebuah karakter dalam garap gending Jawa (Supanggah, 2007:287). Adapun tujuan dari penciptaan yang akan dilakukan sebagai awal penyusunan pathet terhadap instrumen Gender wandu dengan 
menggunakan sistem deretan kempyung, dan mengetahui unsur-unsur musikal yang menjadi pertimbangan dalam penciptaan musik nusantara setelah ditetapkan melalui sistem deretan kempyung.

\section{Aspek Karawitan}

Supanggah (2002: halaman 45). Bothekan Karawitan I. Jakarta: Masyarakat Seni Pertunjukan Indonesia lebih lengkapnya buku ini membahas tentang karawitan dan kelompokkelompok gamelan. Terdiri dari perangkat gamelan, pengaturan penempatan ricikan gamelan, laras, irama, dan gaya dari gaya barang miring, yang meliputi nuansa, karakter melodi, pergerakan harmoni (laras pelog dan laras slendro). Supanggah (2009), Bothekan Karawitan II : Garap. Surakarta: Program Pascasarjana bekerja sama dengan ISI press Surakarta, cukup panjang lebar tentang ricikan atau perangkat laras, pathet dan sistem deret kempyung. Ketiga hal tersebut adalah materi dasar yang sebagian besar merupakan unsur fisik atau indrawi terpenting yang paling mudah untuk mengidentifikasi. Ditegasakan dalam masing-masing laras mempresentasikan 3 pathet. Laras pelog terdiri dari pelog pathet lima atau 5, nem atau 6, dan pathet pelog barang atau 7 . Laras slendro terdiri dari tiga pathet yakni: Laras Slendro pathet sanga atau 9, pathet nem atau 6, dan pathet manyura.

Kajian karya penulis melihat kembali fenomena dari sebuah gending unik dalam penggunaan larasnya seperti Gendhing Laler Mengeng Laras Slendro Barang Miring (anonimus) tersebut tergolong gendhing yang tidak diketahui penciptanya, gendhing lawas/lama oleh empu karawitan yang (juga) berada di anggapan masyarakat memiliki laras campuran yakni laras pelog dan laras slendro. Tetapi pada kenyataannya dalam rumusan laras khususnya di karawitan Jawa memiliki pembagian-pembagian laras tersendiri. Telah disinggung bahwa karawitan (gamelan) Jawa menggunakan dua laras; slendro pada lima nada dengan pola jangkah/interval hampir sama rata, sedangkan laras pelog adalah sistem lima atau tujuh nada dengan pola interval tidak sama rata; tiga atau lima berjarak pendek dan dua berjangkah panjang. Disamping dua laras pakem tersebut, dalam kalangan karawitan juga dikenal laras miring atau barang miring. Sementara beberapa orang berpendapat bahwa laras barang miring adalah beberapa nada pada laras pelog yang dimasukan kedalam penyajian gending laras slendro, biasanya dilakukan oleh Rebab atau vokal sinden. Faktanya menurut Rahayu Supanggah dalam buku 
Bothekan Karawitan I (MSPI) 2002 bahwa sampai saat ini juga belum ada seperangkat gamelan Jawa yang di laras (barang) miring. Jadi kondisi gending Laler Mengeng Laras Slendro Barang Miring saat ini bisa dikatakan masih dalam situasi kolaborasi antara laras slendro yang disisipi laras pelog sehingga (seolah-olah) ini bagian dari jenis laras yang sudah ada.

Kondisi yang ada dalam garap gending Laler Mengeng Laras Slendro Barang Miring saat ini bisa dikatakan masih dalam situasi kolaborasi antara laras slendro yang disisipi laras pelog dan sebaliknya, sehingga dianggap (seolaholah) adalah laras ketiga atau baru. Bisa diartikan pula bahwa kedua gending tersebut merupakan gending yang memiliki laras terpisah yang dicampurkan menjadi satu komposisi. Fenomena gabungannya tergolong temporari atau sementara. Perbedaan dengan karya penulis yaitu bentuk instrumen, tangga nadanya, serta bunyi pada masing-masing nada dengan permanen.

Secara garis besar sebuah karya musik tidak bisa lepas dari paradigma yang dilandasi oleh sebuah teori maupun praktik. Dalam sebuah kebiasaan komponis yang berpengalaman maupun komponis yang masih dalam tahap belajar, ia akan melahirkan karya komposisi musik yang sesuai dengan batas kemampuanya sendiri. Seorang komponis juga harus mencoba sesuatu kemungkinan baru dan kemungkinan-kemungkinan yang lain untuk dimasak sesuai dengan konten yang relevan dalam dunia musik. Baik teknik komposisi, penyajian, maupun artistik panggung sekalipun. Maka dari itu, komponis diwajibkan terus menerus manggali ide-ide kreatif dan bervariatif sebanyak-banyaknya sehingga dalam proses penciptaannya memiliki wawasan yang semakin luas. Penulis sendiri berlatar belakang dari disiplin ilmu Etnomusikologi, dimana ilmu yang sekarang dikembangkan kedalam ilmu penciptaan musik nusantara.

Laras merupakan esensi yang berperan penting dalam dunia Karawitan. Laras memiliki dua konsep khusus yang disebut pelog dan slendro (seperti penjelasan di atas). Dua konsep yang berbeda ini tentunya memiliki karakterkarakter yang berbeda. Laras menjadi salah satu perangkat (software) garap yang cukup penting. Kedua jenis laras tersebut adalah satu dari dua unsur utama yang mencirikan karawitan. Laras dalam dunia karawitan memiki tiga makna jamak yaitu, pertama; sesuatu yang (bersifat) 'enak' atau nikmat untuk didengar atau dihayati, kedua; yaitu suara yang telah ditentukan jumlah frekuensinya (penunggul, gulu, dhadha, pelog, lima, nem dan barang) 
(Supanggah, 2002: 89). Makna yang ketiga adalah tangga nada atau scale, yaitu susunan nada-nada yang jumlah urutan dan pola interval nada-nadanya telah ditentukan. Rasa tersebut berkaitan dengan selera seperti ungkapan Rahayu Supanggah dalam bukunya Bothekan Karawitan I bahwa 'laras memang sangat erat dengan rasa, selera rasa dapat terbentuk oleh budaya, termasuk tradisi dan kebiasaan lokal' (Supanggah, 2002:270).

Pathet dalam wilayah karawitan dianggap sebagai salah satu aturan yang mengikat pengrawit pada saat menabuh ricikan-nya atau melantunkan vokalnya. Pathet adalah salah satu sistem yang mengikat pengrawit bagaimana seyogianya seorang pengrawit nabuh atau melantunkan sebuah tembang, terutama kaitannya dengan pilihan nada dalam membentuk gending/lagu. Ada nada yang terpilih, adapula nada yang dihindari. Pada tradisi karawitan Jawa, terdapat enam buah pathet, masing-masing tiga buah pathet disetiap laras. Pathet bisa diartikan sebagai sistem yang mengatur peran dan kedudukan nada. Pada pathet yang berbeda, tiap-tiap nada memiliki peran, fungsi, dan kedudukan yang berbeda. Suatu nada memiliki kedudukan lebih kuat dan berperan lebih penting dari pada nada yang lain.
Sistem deretan kempyung iyalah cara mudah untuk mengetahui pola-pola pathet. Pathet juga sering diberi makna sebagai konvensi yang memberi batasan pada daerah wilayah suara. Pathet itu sendiri bisa disejajarkan dengan kunci pada konvensi musik diatonis barat. Terdapat beberapa teoritikus yang telah menentukan atau mengidentifikasikan peran tiap-tiap nada dalam pathet tertentu. Kata deretan kempyung ini sendiri merupakan hasil adopsi dari istilah musik blown fifth (kempyung tiup) yang diciptakan oleh Jaap Kunt (Supanggah, 2002:89). Kemudian oleh Sindusawarna diadopsi menjadi deretan kempyung. Pembagiannya ada dua bagan, pertama deretan kempyung untuk laras pelog dan kedua deretan kempyung pada laras slendro (Supanggah, 2002: 90). Pada sistem deretan kempyung, ada nada-nada yang tidak disebut secara eksplisit perannya dalam masing-masing pathet. Penulis mencoba sedikit memberikan contoh perhitungan pathet menurut sistem deretan kempyung.

Berikut pola identifikasi pathet pada laras pelog dengan rumus deretan kempyung oleh Sindusawarna : 


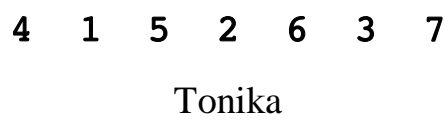

$\begin{array}{llllllllll}4 & 1 & 5 & 2 & 6 & 5 & 2 & 6 & 3 & 7\end{array}$

Pelog Lima Pelog barang

\section{$\begin{array}{lllll}1 & 5 & 2 & 6 & 3\end{array}$}

Pelog Nem

Berikut pola identifikasi pathet pada laras slendro dengan rumus deretan kempyung oleh Sindusawarna :

\author{
$\begin{array}{lllllll}3 & 1 & 5 & 2 & 6 & 3 & 1\end{array}$ \\ Tonika \\ $\begin{array}{llllllllll}3 & 1 & 5 & 2 & 6 & 5 & 2 & 6 & 3 & 1\end{array}$ \\ SlendroSanga Sl. Manyura

\section{$\begin{array}{lllll}1 & 5 & 2 & 6 & 3\end{array}$} \\ Slendro Nem
}

\section{METODE PENELITIAN}

\section{PENCIPTAAN}

Metode penelitian yang digunakan dalam proses penelitian ini adalah practice based research jenis menguji teori. Tahapan penelitian dilakukan melalui praktik dan proses pencipta mulai dari mempersiapkan, mensintesis ide, menentukan konsep, mengimplementasikan dan menguji teori melalui praktik, hingga melakukan serangkaian eksperimentasi, guna memperoleh pengetahuan baru melalui hasil praktik tersebut, serta merealisasikan hasil penelitian berupa karya musik. Praktik dalam practice based research merupakan eksplorasi secara terencana dan sadar dengan pengetahuan yang terlibat dalam proses penciptaan karya. Sebab penelitian menjadi bagian yang saling terkait satu sama lain dengan praktik.

Pengumpulan data dalam penelitian ini menggunakan pendekatan studi kasus. Alasan penggunaan pendekatan ini karena penahapan refleksi membutuhkan data yang meluas dalam memecahkannya satu per-satu. Sumber data yang dikumpulkan meliputi;

1. Pengamatan prosedur penyusunan pathet, baik melalui kajian pustaka, observasi langsung maupun bahan audio visual,

2. W awancara individual dengan orang terkait yang telah melakukan penelitian tentang praktik, baik via email maupun langsung.

Penelitian ini terdiri dari tujuh komponen terpenting:

a) Pengumpulan data pustaka merupakan kajian terhadap sumber tertulis

b) Pengumpulan data eksplorasi merupakan elaborasi aspek intraekstra musikal

c) Analisis data, 
Jurnal Etnomusikologi

d) Penyusunan konsep; sebuah penuangan ide garap berdasarkan hasil penelitian

e) Tahap penyusunan pathet,

f) Tahap penyusunan struktur pathet pada gender wandu,

g) Tahap pengaplikasian konsep dan struktur. h) Komponen-komponen ini telah digunakan relatif bersamaan, sebab saling mempengaruhi satu sama lain dan di analisis dan di interpretasi kembali (refleksi) secara berulangulang selama proses penciptaan ini (lihat Skema 1).

Skema 1.

Kerangka Proses Practice based research dalam penciptaan karya.

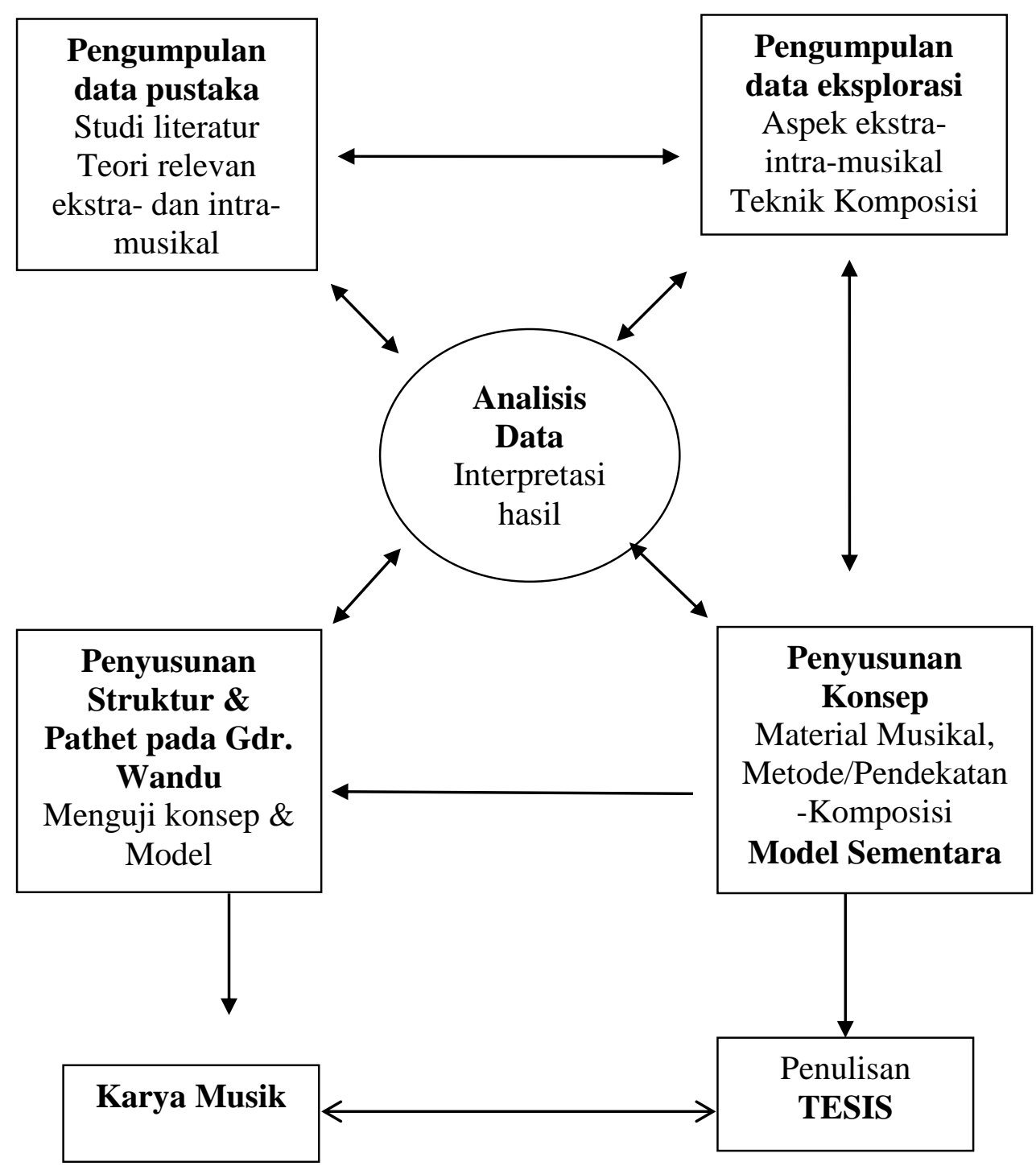




\section{Hasil dan Pembahasan}

Pengumpulan data pustaka, meliputi studi literatur yang berhubungan dengan konten ekstra-musikal ide/gagasan awal penciptaan (representasi pathet) dan teoriteori yang relevan untuk mendukung konsep penciptaan. Penjelasan bentukbentuk seni bebas untuk melakukan aktifitas hingga sampai pada pengaruh garap karawitan. Melalui hasil pengumpulan data pustaka penulis merelevansikan dengan pengumpulan data eksplorasi terkait dengan representasi pathet pada instrumen Gender wandu dengan menggunakan sistem deret kempyung. Untuk lebih jelasnya perhatikan skema berikut (Skema 2).

Skema 2.

Perhitungan representasi pathet

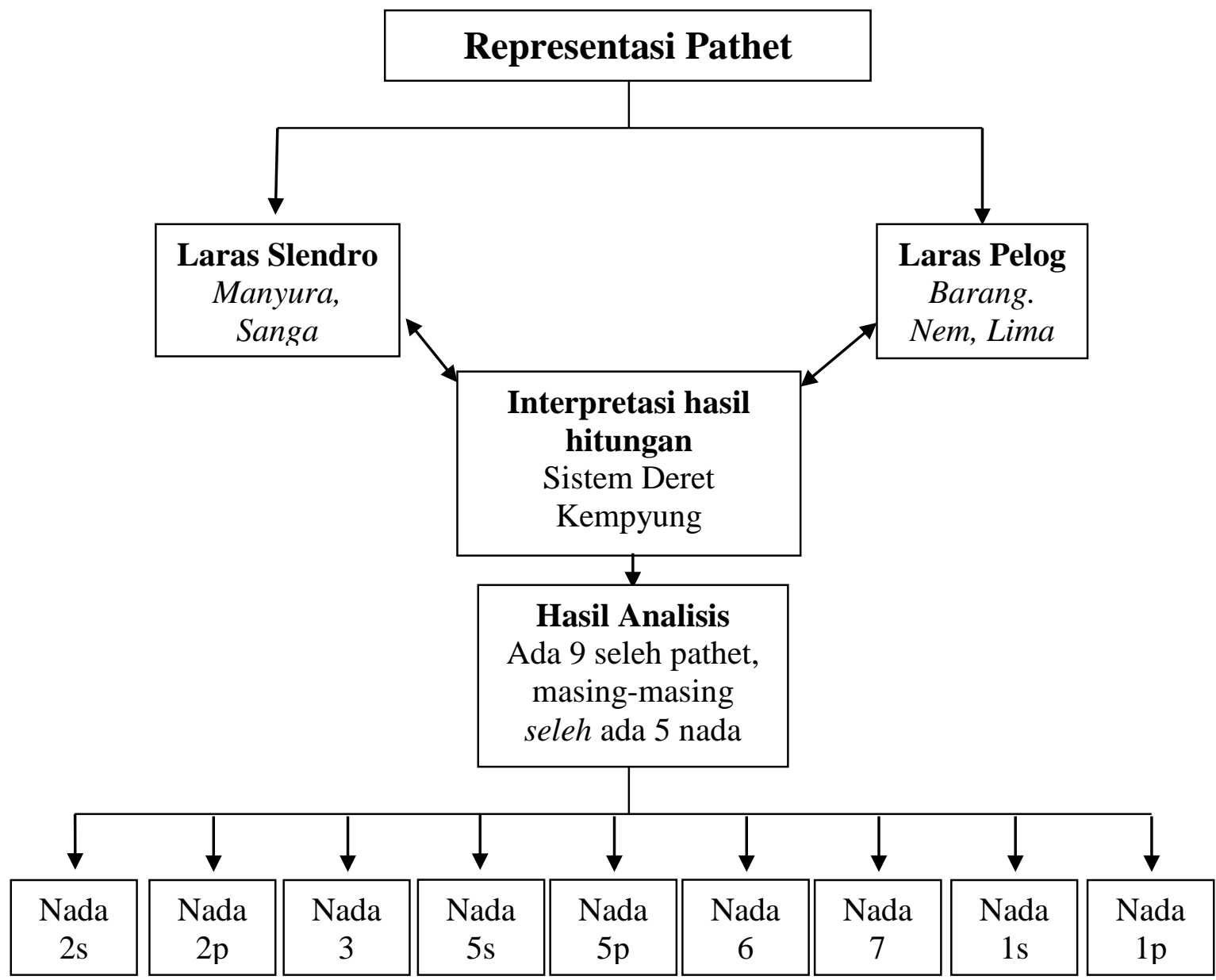


Perhitungan pemilihan nada dasar yang akan ditarik ke sistem deret kempyung penulis membagi dua komponen, yaitu pertama; representasi pathet dari laras slendro pada Gender wandu danm kedua; representasi pathet dari laras pelog pada Gender wandu, hingga ketemu hasil hitungan dari sistem deret kempyung. Kemudian ditarik wilayah nada-nada yang menjadi tonika sekaligus dianggap seleh nada hingga dibentuklah pola tabuhan sesuai selehseleh tersebut pada masing-masing nada.

Setelah menentukan seleh dan cengkok tabuhan instrumen Gender wandu saatnya pencipta melakukan simulasi bentuk garapan dan teknik penyusunan komposisi. Pengaplikasian hasil perhitungan sesuai penjabaran diatas tersebut nantinya akan diproyeksikan dalam bentuk audio-visual (gendingpengrawit). Akan tetapi bentuk gending yang disajikan tidak sama dengan bentukbentuk gending pada umumnya yang tentu sistem kolotomis yang paten serta selehseleh yang dirasa enak dan sebagainya.

Untuk menyelesaikan uraian diatas tersebut, beberapa pengaturan atau perlakuan (teknis) tertentu harus dipertimbangkan dan ditetapkan. Pada kesempatan kali ini pencipta bereksperimen mempertimbangkan dan menetapkan kemungkinan-kemungkinan yang memungkinkan sebagai pengaturan. Aspek yang dipertimbangkan yaitu capaian kejelasan minimal dalam proyeksi representasi pathet pada Gender wandu. Langkah selanjutnya setelah proses eksperimentasi penggabungan pathet pada laras pelog dan pathet pada laras slendro, maka timbulah sensasi nada yang berbeda dari hasil penyilangan keduanya (hybrid) yang dilakukan dan disimulasikan pada instrumennya langsung, pencipta mulai mengeksekusi material yang sudah terkumpul.

Terkait representasi secara objektif dan subjektif pencipta mulai melakukan penyusunan dengan interpretasi kognitif. Termasuk sensasi-sensasi pada masingmasing pathet dalam laras slendro, laras pelog dan laras wandu yang lebih familiar secara objektif maupun subjektif dianggap pencerminan karakter seseorang. Menurut eksistensi mengikuti perkembangan jaman garap gending-gending di Jawa komposisinya terlihat lebih mengkarakter. Melirik gending-gending konsumsi laras pelog, Ki Narto Sabdo menduduki wilayah terbanyak menciptakan lagu-lagu kasmaran, kesedihan, kemayu, dan centil, pencipta menyebut situasi tersebut adalah sifat feminin. Melihat kondisi bahwa laras slendro mendominasi sifat-sifat maskulin 
dikarenakan kebiasaan turun-temurun pada keraton Yogyakarta untuk menggelar pagelaran tari yang bernafaskan kegagahan, jiwa pahlawan (prajurit), garis peperangan sehingga konsumsi laras slendro menjadi dominan. Sisi tersebut pencipta menyebut sifat maskulin. Lalu pada kondisi Gender laras wandu ini, pencipta mengingat kembali sebuah pengalaman pribadi, perilaku sosial masyarakat, hingga kebiasaan manusia secara psikis maupun biologis terhadap lingkungan para transgender. Pemilihan karakter transgender kali ini dapat dilihat dari sudut pandang ide gagasan awal saat S1. Selain itu, nada-nada yang ada pada Gender wandu ini memang berada diantara kedua laras pelog dan laras slendro, maka secara logika lebih tepat dipaparkan pada posisi ditengah, diantaranya (transgender).
Dapat diimajikan tingkatan rasa seleh-nya sudah pasti berbeda. Kemudian pencipta akan menetapkan garis melodi, dan harmoni utama, dan garis melodi dan harmoni sekunder (counterpart) yang dieksekusi melalui beberapa pengaturan tertentu (Untuk lebih jelasnya perhatikan skema berikut (Skema 3)

Pada tahap ini merupakan hasil sementara (prototipe karya). Hasil simulasi karya berupa audio rekaman yang menjadi objek audio-visual dalam mengevaluasi karya. Proses evaluasi melibatkan partisipan (pendengar, praktisi, baik komposer maupun pemain) yang membantu menilai apakah karya (simulasi) telah relatif merepresentasikan pathet. 


\section{Skema 3.}

Proses penyusunan data eksplorasi pada Gender wandu.

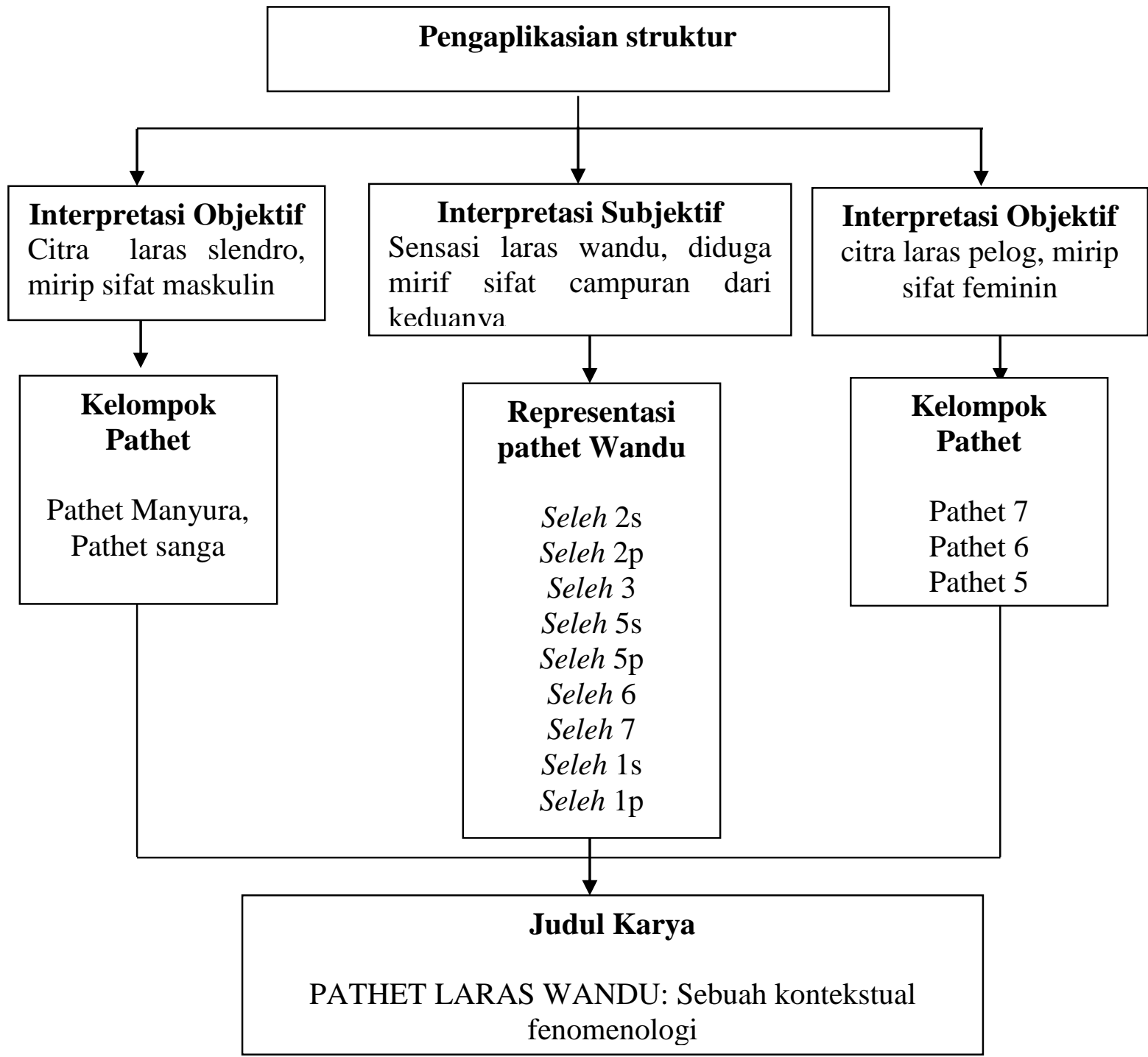

\section{SIMPULAN}

Berdasarkan hasil analisis dan pembahasan dapat disimpulkan bahwa Aspek pendukung yang dapat digunakan dalam penciptaan musik berdasarkan pengaruh Gender wandu adalah sistem deret kempyung yang kemudian menjadi seleh yang berkarakter sesuai warna bunyinya, metode penyilangan (crossing) seleh dan harmoni kempyung. Melalui aspek-aspek musikal tersebut, dapat dihasilkan (secara seleh/pathet) kesatuan dua kondisi musikal kontradiktif yang menyambung dengan ketidaknyamanan pencipta atas kondisi intra-musikal (Gender wandu) sebagai gagasan/ide penciptaan. 


\section{DAFTAR PUSTAKA}

Bijdragen tot de Taal-, Land- en Volkenkunde, The textures of Central Javanese gamelan music: Pre-notation and its discontents, Vol. 164, No. 4 (2008).

Candy, Linda. 2006. Practice Based Research: A Guide. Australia: University of Technologi Sydney.

Djuli Djatiprambudi, Seminar Nasional Seni dan Desain: "Membangun Tradisi Inovasi Melalui Riset Berbasis Praktik Seni dan Desain" FBS Unesa, 28 Oktober 2017.

Joseph, Machlis. (1995). The Enjoyment of Music: An IntroductiontoPerceptive listening, W. W. Norton \& Company. INC, New York.

Kardi Laksono, Resital, Journal of performing art Musik, Hip-Hop sebagai Bentuk Hybrid Culture dalam Tinjauan Estetika, vol. 16 no. 2, 2015 .

Martoprangrawit, Pengetahuan Karawitan Jilid I, Surakarta: STSI Press.

Nakagawa, Shin. (2000). Musik dan Kosmos: Sebuah Pengantar
Etnomusikologi Yayasan Obor Indonesia.

Prier SJ, Karl Edmund. (1996). Ilmu Bentuk Musik, Pusat Musik Liturgi, Yogyakarta.

Read, Harbert. (1993), Pengertian Seni Terj. Soedarsono Sp. Saku Dayar Sana, Yogyakarta.

Stein, Leon. (1979), Structure and Analysis of Musical Form, Summy-Bichard Music, New Jersey.

Sumarsam. (2003), Gamelan, Interaksi Budaya dan Perkembangan Musikal di Jawa, Pustaka Belajar, Yogyakarta.

Supanggah, Rahayu. (2002). Bothekan Karawitan I. Jakarta: Ford Foundation \& Masyarakat Seni Pertunjukan Indonesia.

\begin{tabular}{l}
\hline $\begin{array}{l}\text { Karawitan II; } \\
\text { Surakarta: ISI Press. }\end{array}$ \\
Wentle GARAP. \\
$\begin{array}{l}\text { E. C., The Journal of The } \\
\text { Acoustical Society of America, } \\
\text { vol. VII, no. 1. }\end{array}$
\end{tabular}

